Kapata Arkeologi, 13(2), 141-150

ISSN (cetak): 1858-4101

ISSN (elektronik): 2503-0876

http://kapata-arkeologi.kemdikbud.go.id

\title{
KEBIJAKAN PENGELOLAAN WARISAN BUDAYA DITINJAU DARI UNDANG-UNDANG NOMOR 11 TAHUN 2010 (PERIHAL PEMBERIAN INSENTIF DAN KOMPENSASI)
}

\section{Heritage Management Policy From Statutory of Cultural Heritage No. 11/2010, (Regarding Granting Incentives and Compensation)}

Karyamantha Surbakti

Universitas Indonesia - Indonesia

Fakultas Ilmu Pengetahuan Budaya, Kampus UI, Depok 16424

manthatorong@gmail.com

Naskah diterima: 25/03/2017; direvisi: 17/10—21/11/2017; disetujui: 25/11/2017

Publikasi elektronik: 30/11/2017

\begin{abstract}
Several articles of various legal provisions outside Statutory of Cultural Heritage No. 11/2010 concerning cultural heritage have mentioned the issue of incentives and compensation. The incentives and compensation here is given by the government when the public has an cultural heritage objects. The government provides relief by not imposing tax status to the communities that have cultural heritage in the form of sites or buildings. The purpose of this conceptual framework is to identify and recognize how the government seeks to pay attention to aspects of participating communities to protect and preserved cultural heritage. The approached adopted in this study is literature review, using Statutory of land and bulding tax No.12/1994 and the regulation of Public Works and Public Housing Republic of Indonesia No.1/PRT/M/2015 as the main source and some articles related to cultural heritage. The results of the discussion provide an illustration that the government is pursuing a legal product related to incentives and compensation to people who have ancient relics as an effort for the preservation of cultural heritage pertaining to the community.
\end{abstract}

Keywords: Law on Cultural Heritage, Archeological Remains, Incentives, Compensation

\begin{abstract}
Abstrak
Beberapa pasal dari berbagai ketetapan hukum di luar Undang-undang Nomor 11 Tahun 2010 mengenai cagar budaya, telah menyebutkan dan mencantumkan perihal pemberian insentif dan kompensasi. Insentif dan kompensasi di sini diberikan oleh pemerintah ketika masyarakat memiliki suatu peninggalan purbakala. Pemerintah memberikan keringanan dengan tidak mengenakan status pajak kepada masyarakat yang memiliki warisan budaya/cagar budaya berupa situs atau bangunan. Tujuan dari kerangka konseptual ini adalah untuk mengenali bagaimana pemerintah berusaha memperhatikan aspek masyarakat yang berpartisipasi untuk melindungi dan menjaga cagar budaya. Pengumpulan data dilakukan melalui telaah pustaka, dengan menggunakan Undang-undang Pajak Bumi Bangunan Nomor 12 Tahun 1994 serta Peraturan Menteri Pekerjaan Umum dan Perumahan Rakyat RI Nomor 1/PRT/M/2015 sebagai sumber utama dan beberapa tulisan yang berkaitan dengan cagar budaya. Hasil pembahasan memberikan gambaran bahwa pemerintah mengupayakan sebuah produk hukum yang berkenaan dengan insentif dan kompensasi kepada masyarakat yang memiliki peninggalan purbakala sebagai usaha untuk pelestarian cagar budaya yang bersinggungan dengan masyarakat.
\end{abstract}

Kata kunci: Undang-undang Cagar Budaya, Peninggalan Purbakala, Insentif, Kompensasi 


\section{PENDAHULUAN}

Tulisan ini membahas bagaimana perkembangan arkeologi kontemporer sekarang ini, dengan melihat beberapa kebijakan (legal outstanding) yang melibatkan aspek hukum sebagai pendekatan dalam pembahasannya. Arkeologi kontemporer yang dimaksud di sini menurut Magetsari (1990) adalah kajian yang perkembangannya dituntut oleh masyarakat untuk menghasilkan apa yang disebut valuecommitted archaeology. Adapun yang dimaksud dengan value-comitted archaeology adalah bagaimana setiap kajian arkeologis yang dilakukan oleh pihak yang berotoritas, yaitu pemerintah harus bisa melihat kemaslahatan masyarakat (Magetsari, 1990). Setiap kajian arkeologi dan semua produk hukum yang berkenaan, harus bisa peka dengan kebutuhan masyarakat yang dimaksud. Permasalahan mengenai tinggalan arkeologi yang bersinggungan dengan masyarakat sebagaimana halnya museologi (ilmu permuseuman), merupakan sebuah ranah kajian CRM (Cultural Resources Management) yang bisa dikategorikan sebagai arkeologi kontemporer dengan pembahasan yang bersisian terhadap Undangundang dan stakeholder (pemangku kepentingan).

Tulisan ini mencoba mengkaji beberapa pasal yang bisa diperbandingkan dari produk hukum lainnya diluar Undang-undang Cagar Budaya Nomor 11 Tahun 2010, yaitu berkaitan dengan pemberian insentif dan kompensasi. Perihal pemberian insentif dan kompensasi, memang jelas diatur pada pasal 22 di Undangundang Cagar Budaya Nomor 11 Tahun 2010. Setiap orang individu ataupun kelompok dalam masyarakat tertentu, memiliki kewajiban yang sama jika sudah bersinggungan dengan cagar budaya (Undang-undang RI, 2010). Undangundang Nomor 11 Tahun 2010 tentang Cagar Budaya (selanjutnya dalam tulisan ini disingkat CB) merupakan sebuah jenis hukum yang tergolong hukum yang mengatur masalah publik. Dalam hal ini termasuk aturan tentang insentif dan kompensasi, yang berkaitan dengan elemen yang terlibat di dalamnya.

Dalam konteks Undang-undang sebagai produk hukum, maka sebagai pengantar perlu dijabarkan terlebih dahulu sifat hukum dan beberapa pendekatan yang dikenal di Indonesia. Secara gamblang dapat kita artikan bahwa hukum merupakan sebuah produk tata tertib dalam masyarakat. Akan tetapi tidak semua orang mau menaati kaidah-kaidah hukum, dan agar sesuatu peraturan hidup kemasyarakatan benar-benar dipatuhi dan ditaati sehingga menjadi kaidah hukum, maka peraturan hidup kemasyarakatan harus dilengkapi dengan unsur memaksa. Dengan demikian, hukum itu mempunyai sifat mengatur dan memaksa. Ia merupakan peraturan-peraturan hidup kemasyarakatan yang dapat memaksa orang supaya menaati tata tertib dalam masyarakat serta memberikan sanksi yang tegas, yaitu berupa hukuman terhadap siapa saja, baik individu, kelompok, golongan, dan bahkan korporasi tertentu yang tidak mau patuh menaatinya (Kansil, 2014: 35).

Mengingat Undang-undang CB Nomor 11 Tahun 2010 sebagai pokok acuan, merupakan sebuah produk hukum yang mengatur secara eksplisit seorang individu ataupun kelompok masyarakat agar mematuhi pasal demi pasal yang terkandung di dalamnya. Undang-undang CB Nomor 11 Tahun 2010 ini, sebagai acuan untuk melihat Cagar Budaya dalam perspektif penemuan, pencarian, perlindungan, pengembangan, pemanfaatan, wewenang, pengawasan, dan penyidikan. Pandangan global terkait arkeologi publik dan juga heritage studies di dunia dan juga yang sudah dikenal dan diterapkan di Indonesia ditulis oleh seorang sarjana bernama Rodney Harrison. Menurut Harrison (2013), bahwa arkeologi publik harus menyasar banyak hal, sehingga keterlibatan publik atau khalayak luas bisa terwujud. Seperti yang diutarakan demikian:

"Throughout developed three interlinked themes-connection, materiality and dialogueas ways of thinking about what heritage is and does in contemporary global societies future of heritage studies and try to reinforce some of the implications of the 'toolkit of concepts' that I have developed here. In doing so, I emphasise the ways in which critical interdisciplinary approaches to heritage might have an influence on the global practice of heritage, and hence have a lasting impact on important social, political, economic and environmental issues in the future." (Harrison, 2013: 227).

Masyarakat harus dapat diakomodir sedemikian rupa dengan keadaaan dan 
pendekatan yang beragam, terlebih bila melihat kondisi masyarakat modern dewasa ini (contemporary global societies) sangat heterogen sehingga konsep dialogis antara cagar budaya (materialitas) dan masyarakat sekarang bisa terwujud.

Pentingnya juga untuk melihat dampak terhadap cagar budaya dengan perangkat hukum yang tersedia (baca: ragam pasal dan ayat) harus selalu bisa disesuaikan dengan (current issues) yang akan berkembang di kemudian hari. Masih menurut Harrison (2013), seperti yang diutarakannya demikian:

"That heritage is a distinctly modern concern, in the sense in which the question of what is 'old' and what is 'new' belongs to a peculiarly modern sensibility. This sensibility arises from the experience of modernity and its relationship to time, ordering and uncertainty (or 'risk'). These three concepts are integrally linked-modernity must order and classify to deal with uncertainty and risk; uncertainty derives from a sense of the accelerated passage of time; linear time provides one of a series of principles of ordering and classification to manage uncertainty. Together, they are responsible for the development of our modern conception of heritage as salvage or preservation of that which is distant, old, hidden and hence authentic, as opposed to the notion of heritage as a form of creative production involving the assembly and reassembly of things on the surface and in the present, which I have emphasised throughout the book. The accelerated operation of this modern sensibility, coupled with a series of factors, including shifting economic and demographic processes of deindustrialisation and redundancy; the development of the heritage 'experience' as a marketable commodity; the growth of domestic and international leisure travel and the accompanying restructuring of the tourist gaze and its economic and social impacts; the diversification and segmentation of heritage to make it marketable to more varied audiences; and the globalisation of the World Heritage concept, have contributed to the abundance of heritage which I have suggested characterises our late-modern world." (Harrison, 2013: 228).
Menurut penjelasan tersebut, bahwa publik memiliki tanggung jawab untuk melestarikan warisan budaya (heritage). Konsep salvaged (menyelamatkan) dan preservation (memelihara) yang disebutkan, menjadi dasar pelibatan publik yang notabene bersinggungan dengan tinggalan masa lampau yang ada di masa sekarang. Masyarakat mungkin saja memiliki suatu benda artefaktual atau bangunan bersejarah dikarenakan warisan, hibah, atau sebuah akses yang memungkinkan mereka bersisian dengan tinggalan masa lalu.

Terlebih dahulu akan dibahas mengenai perjalanan atau pun kilas balik pengelolaan warisan budaya di Indonesia dan nilai penting dari warisan budaya itu sendiri, serta perkembangan dari produk hukum hingga munculnya Undang-undang yang berkenaan dengan warisan budaya atau cagar budaya yang kita kenal sekarang ini. Kesadaran akan pentingnya pengelolaan dan pelestarian warisan budaya kini sudah semakin meninggi. Bahkan, banyak diantara para pencinta dan pemerhati warisan budaya yang berkeyakinan bahwa sumber daya budaya itu tidak saja merupakan warisan, tetapi lebih-lebih adalah pusaka bagi bangsa Indonesia. Artinya, sumber daya budaya itu mempunyai kekuatan yang dapat dimanfaatkan untuk membantu dan melindungi bangsa ini dalam menapaki jalan ke masa depan. Sebagai pusaka, warisan budaya itu harus tetap dijaga agar kekuatannya tidak hilang dan dapat diwariskan kepada generasi penerus tanpa berkurang nilainya.

Namun jika ditelisik lebih teliti, perkembangan pengelolaan warisan budaya di Indonesia jelas menunjukkan bahwa minat terhadap warisan budaya di Indonesia dan upaya pelestariannya muncul dan berkembang dalam alam dan lingkungan kolonial. Terutama atas usaha komunitas Eropa pencinta barang seni dan benda unik-antik. Acapkali G.E. Rumphius, seorang ahli ilmu alam yang banyak berkarya di Maluku, disebut-sebut sebagai salah satu ilmuwan yang memicu minat terhadap warisan budaya di Indonesia. Pada tahun 1705, tokoh sarjana ini menerbitkan buku berjudul $D$ ' Amboinsche Rariteitkamer yang beberapa bagiannya menguraikan tentang temuan kuno seperti kapak batu, kapak perunggu dan nekara (sejenis genderang) perunggu serta mitos-mitos yang ada di balik benda-benda itu. Sejak itu, banyak peminat benda unik-antik mulai 
melakukan penelitian dan mengoleksi tinggalantinggalan masa lampau, termasuk batu-batu candi dan benda-benda dari masa prasejarah. Bahkan, pada tahun 1778 berdirilah organisasi peminat dan peneliti benda seni dan antik yang diberi nama Koninklijk Bataviaasch Genootschap van Kunsten en Wetenschappen. Badan ini mendirikan museum yang kini menjadi Museum Nasional di Jakarta (Suleiman et al., 1976; Tanudirjo, 1995).

Ketika Sir Thomas S. Raffles berkuasa di Indonesia (awal abad 19), penelitian terhadap warisan budaya Indonesia meningkat. Sebagian hasilnya diuraikan dalam buku The History of Java. Setelah Belanda kembali berkuasa kembali di Indonesia, benda warisan budaya Indonesia dianggap akan dapat meningkatkan citra mereka di luar negeri. Karena itu, mereka membentuk komisi khusus yang menangani warisan budaya di Indonesia pada tahun 1822. Dapat dikatakan, pada saat itulah upaya pengelolaan warisan budaya untuk pertama kalinya menjadi urusan lembaga pemerintahan, meskipun kerja komisi itu sebenarnya tidak cukup efektif. Dengan alasan itu pula, pada tahun 1885, maka lahirlah perkumpulan peminat tinggalan sejarah dan purbakala amatir di Yogyakarta. Salah satu warisan lembaga ini adalah Museum Sono Budoyo di dekat Kraton Yogyakarta (Tanudirjo, 2003: 2).

Masih menurut Tanudirjo (2003) pada tahun 1900, benda-benda warisan budaya Indonesia dipamerkan dalam Pameran Kolonial Internasional di Paris dan mendapat perhatian yang luar biasa dari khalayak Eropa (Tanudirjo, 2003: 3). Sukses ini mendorong pemerintah kolonial Belanda untuk menggiatkan lagi komisi yang dulu pernah ada. J.L.A. Brandes ditunjuk menjadi ketua lembaga yang dinamai Commisie in Nederlandsche-Indie voor Oudheidkundige Onderzoek op Java en Madoera. Komisi ini bekerja aktif cuma hingga tahun 1905 dan kinerjanya merosot setelah ditinggal wafat Brandes tahun itu juga. Penggantinya N.J. Krom, baru ditunjuk pada tahun 1910. Krom menganggap pengelolaan warisan budaya di Indonesia tidak mungkin hanya ditangani oleh sebuah komisi, karena begitu banyaknya jumlah dan ragam warisan budaya yang ada. Karena itu, Krom lalu mengusulkan agar 'komisi' tersebut ditingkatkan menjadi 'jawatan' atau 'dinas' dengan diperkuat oleh para peneliti arkeologi dan sejarah yang handal.
Atas desakan Krom, pada tanggal 14 Juni 1913 pemerintah Belanda mendirikan Oudheidkundige Dienst in Nederlandsche-Indie (Jawatan atau Dinas Purbakala di NederlandIndie). Sejak saat itu, semua urusan yang berkaitan dengan warisan budaya di negara ini, termasuk upaya untuk mengumpulkan, mendaftar, meneliti, serta melestarikan dan memanfaatkannya menjadi urusan negara. Di lingkungan arkeologi, pelembagaan urusan warisan budaya (benda-benda arkeologi) seperti itu disebut sebagai "archaeology in the service of the state" atau 'arkeologi pengabdi negara.' Peran negara menjadi semakin kuat dengan ditetapkannya Monumenten Ordonantie (MO) No. 19 tahun 1931 Staatblad 238 (diperbaiki tahun 1934). Ketentuan dalam ordonansi itu menyiratkan begitu besar penguasaan negara atas warisan budaya. Hal ini dapat dipahami karena pada dasarnya MO 1931 merupakan upaya pemerintah colonial Belanda untuk menjamin akses mereka terhadap warisan budaya milik bangsa Indonesia. Dengan begitu, para peneliti dan peminat benda cagar budaya yang mayoritas orang Eropa dapat lebih leluasa melakukan eksplorasi sumberdaya budaya itu.

Setelah Indonesia merdeka, pengelolaan warisan budaya dilakukan oleh bangsa Indonesia sendiri. Namun, kebijakan pengelolaan tidak mengalami perubahan berarti. Monumenten Ordonantie 1931 tetap menjadi landasannya. Pada umumnya, mereka memaknai warisan budaya secara 'formal' sebagaimana disebut dalam MO 1931 yang lebih menekankan nilai penting dari segi keilmuan. Padahal, masyarakat tentu memiliki pemaknaannya sendiri yang lebih beragam dan umumnya bersifat praktis. Akibatnya, upaya pengelolaan warisan budaya di Indonesia seringkali diwarnai dengan konflik kepentingan antara masyarakat dan pemerintah (Tanudirjo, 2003: 4).

Ketika Undang-undang baru tentang benda cagar budaya pengganti MO 1931 dirancang pada awal 1990-an, cara pandang yang lama itu tanpa disadari masih tetap dipakai. Tidak mengherankan, Undang-undang Nomor 5 Tahun 1992 tentang Benda Cagar Budaya (UU BCB) yang dihasilkan tidak jauh berbeda dengan MO 1931. Peranan negara dalam pengelolaan warisan budaya tetap dominan dan cenderung menjadi bagian dari birokrasi pemerintahan. Sementara itu hak dan partisipatif masyarakat luas belum dapat diwadahi dengan selayaknya. 
Disamping itu, harus pula diperhatikan bahwa arti penting setiap warisan budaya juga berjenjang. Walaupun pada dasarnya warisan budaya di suatu tempat adalah warisan budaya semua orang, pada kenyataannya pemaknaan setiap warisan budaya tidak sama tingkat lokal, nasional, regional, maupun internasional. Selain itu, maraknya euphoria otonomi daerah telah menambah daftar panjang kasus konflik dalam pengelolaan warisan budaya. Setiap daerah merasa memiliki hak terhadap warisan budaya tertentu melebihi hak daerah lain maupun pemerintah pusat. Karena itu, tidak jarang pemerintah daerah menerapkan kebijakannya sendiri yang seringkali justru memperuncing konflik dan malah mengikis nilai-nilai warisan budaya sebagai pusaka bangsa.

\section{METODE}

Metode pengumpulan data yang digunakan adalah dengan cara observasi pustaka (literatur) yang berkaitan dengan arkeologi publik yang pembahasannya seputar bagaimana komunikasi yang terjadi antara masyarakat masa sekarang dengan tinggalan masa lalu. Komunikasi tersebut bersifat latent (terpendam), yaitu tinggalan cagar budaya yang merupakan hasil kebudayaan masa lalu, namun masih bertahan di masa sekarang dalam aktivitas masyarakat. Telaah literatur dan mengomparasikan beberapa bunyi peraturan perundang-undangan terkait, disini penulis menggunakan kumpulan perundang-undangan yang berkaitan dengan Undang-undang CB Nomor 11 Tahun 2010, Undang-undang Nomor 12 Tahun 1994, tentang Pajak Bumi dan Bangunan serta Peraturan Menteri Pekerjaan Umum dan Perumahan Rakyat Republik Indonesia Nomor 1/PRT/M/2015 berkenaan dengan masalah insentif dan kompensasi.

\section{HASIL DAN PEMBAHASAN}

Telah dibahas di bagian pendahuluan berkenaan dengan sebuah perjalanan produk hukum dari zaman kolonial Belanda, berupa Commisie in Nederlandsche-Indie voor Oudheidkundige Onderzoek op Java en Madoera 1905, MO 1931 hingga Undang-undang BCB Nomor 5 Tahun 1992. Undang-undang CB Nomor 11 Tahun 2010 merupakan sebuah pembaruan dan penambahan dari perundangundangan sebelumnya agar dapat mengakomodir setiap partisipasi masyarakat agar upaya pelestarian cagar budaya dapat dilakukan. Pembahasan dalam tulisan ini menjelaskan bagaimana produk hukum lainnya diluar Undang-undang CB Nomor 11 Tahun 2010 dapat memberikan gambaran jelas mengenai insentif dan kompensasi dalam pelaksanaannya. Undangundang yang digunakan sebagai komparasi adalah Undang-undang Nomor 12 Tahun 1994 Tentang Pajak Bumi dan Bangunan, serta Peraturan Menteri Pekerjaan Umum dan Perumahan Rakyat RI Nomor 1/PRT/M/2015. Kedua Undang-undang tersebut secara jelas menyebutkan adanya pemahaman insentif dan kompensasi dalam hal kaitannya dengan cagar budaya.

Pertama-tama dapat ditinjau terlebih dahulu pasal 22 pada Undang-undang CB Nomor 11 Tahun 2010 yang menyebutkan istilah insentif dan kompensasi.

Undang-undang Nomor 11 Tahun 2010

Pasal 22:

1. Setiap orang yang memiliki dan/atau menguasai Cagar Budaya berhak memperoleh kompensasi apabila telah melakukan kewajibannnya melindungi Cagar Budaya.

2. Insentif berupa pengurangan pajak bumi dan bangunan dan/atau pajak penghasilan dapat diberikan oleh Pemerintah atau Pemerintah Daerah kepada pemilik Cagar Budaya yeng telah melakukan pelindungan Cagar Budaya sesuai dengan ketentuan peraturan perundang-undangan.

3. Ketentuan lebih lanjut mengenai pemberian kompensasi dan insentif sebagaimana dimaksud pada ayat (1), ayat (2), dan ayat (3) diatur dalam Peraturan Pemerintah.

Keterkaitan dengan:

Undang-undang Nomor 12 Tahun 1994 tentang Pajak Bumi dan Bangunan disebutkan dalam:

Pasal 3

1. Objek Pajak yang tidak dikenakan Pajak Bumi dan Bangunan adalah objek pajak yang:

a) digunakan semata-mata untuk melayani kepentingan umum di bidang ibadah, sosial, kesehatan, pendidikan dan kebudayaan nasional, yang tidak dimaksudkan untuk memperoleh keuntungan;

b) digunakan untuk kuburan, peninggalan purbakala, atau yang sejenis dengan itu; 
c) merupakan hutan lindung, hutan suaka alam, hutan wisata, taman nasional, tanah penggembalaan yang dikuasai oleh desa, dan tanah negara yang belum dibebani suatu hak;

d) digunakan oleh perwakilan diplomatik, konsulat berdasarkan asas perlakuan timbal balik;

e) digunakan oleh badan atau perwakilan organisasi internasional yang ditentukan oleh Menteri Keuangan.

Disini berdasarkan isi tersebut, didapatkan penjelasan bahwa terdapat sebuah keterkaitan antara Undang-undang CB No. 11 Tahun 2010 yang memberikan penekanan masalah kompensasi. Menurut Kamus Besar Bahasa Indonesia Pusat Bahasa Edisi Keempat (Tim Penyusun, 2008: 719), bahwa kompensasi adalah imbalan berupa uang atau bukan uang, yang diberikan kepada perorangan atau sebuah organisasi. Pengertian disini menurut kamus bahasa Indonesia adalah sebuah keringanan untuk memudahkan seseorang yang dalam hal ini kepemilikan sebuah warisan budaya tertentu. Kompensasi juga bisa berarti keringanan untuk setiap orang yang memiliki dan/atau menguasai Cagar Budaya. Keringanan tersebut menurut penjelasan Undang-undang Nomor 12 Tahun 1994 mengenai Pajak Bumi dan Bangunan (pasal 3 ayat b) merupakan sebuah penekanan, bahwa negara menjamin lewat Undang-undang Pajak Bumi dan Bangunan akan diberikan keringanan dan serta-merta tidak diterapkan objek pajak pada bangunan peninggalan purbakala. Peninggalan purbakala disini merupakan sebuah istilah yang disematkan pada sebuah daerah yang terdapat tinggalan arkeologis di dalamnya. Walaupun tidak ada penggantian sejumlah uang tertentu disini, dikatakan usaha pemerintah Indonesia untuk tetap mengkonversinya dengan tidak memberlakukan tarif objek pajak pada sebidang tanah atau bangunan pada umumnya.

Penjelasan tersebut di atas butir (b), bahwa peninggalan purbakala tidak dikenakan objek pajak oleh negara. Hal ini memberikan gambaran bahwa Undang-undang Nomor 12 Tahun 1994 tentang Pajak Bumi dan Bangunan dapat menjadi pegangan hukum yang kuat walaupun peraturan tersebut dikeluarkan sebelum munculnya Undang-undang Cagar Budaya di tahun 2010 atau 16 tahun sesudahnya, namun tetap memiliki kekuatan hukum yang tetap dan mengikat setiap warga negara yang tinggal di kawasan purbakala (baca: situs arkeologis). Cakupan individu/ perorangan dalam sebuah komunal masyarakat tertentu memiliki kewajiban dalam melaporkan dirinya sebagai wajib pajak yang tidak dikenakan objek pajak dikarenakan kondisi khusus yang dimaksud tersebut. Masyarakat juga memiliki hak untuk melestarikan situs dan peninggalan purbakala yang ada, dengan keringanan yang diberikan oleh pemerintah berdasarkan peraturan perundang-undangan yang berlaku.

Dengan peraturan seperti itu, pemerintah mengharapkan adanya kesadaran masyarakat untuk melaporkan jika mereka memiliki (jika mengikuti istilah dalam butir b) peninggalan purbakala, baik berupa apa pun yang sangat bernilai, seperti rumah bersejarah, perhiasan, ataupun barang unik-antik lainnya. Secara tidak langsung hal tersirat yang bisa dilihat disini adalah unsur peraturan tersebut mencoba berkomunikasi dengan publik, baik perorangan maupun masyarakat luas agar tercegahnya pemasaran gelap, penjarahan dan aspek ilegal lainnya yang mencoba memanfaatkan properti kultural dengan cara yang tidak bertanggung jawab. Dalam sistem pemasaran global untuk sebuah properti kultural, pada beberapa tingkatan, banyak terjadi penjarahan gelap yang dilakukan secara individu pada situs arkeologis. Artefak kemudian dipindahkan melalui sebuah rangkaian saluran legal dan ilegal hingga tiba di ruang pemasaran rumah pelelangan untuk dijual kepada kolektor pribadi, atau museum yang menutup mata dalam mempertanyakan asal sumbernya.

Studi Morag Kersel (2009), menyebutkan bahwa penelitian multi-sited (banyak situs), dan penyelidikan etnografi di situs purbakala banyak didapati peristiwa yang merefleksikan kenyataan semacam adanya penggelapan peninggalan purbakala (Kersel, 2009: 178). Kebanyakan ditemukan di lapangan bahwa masyarakat tidak melaporkan kepada pemerintah walaupun kenyataannya mereka memiliki artefak yang sangat berharga dan bernilai ekonomis karena kekhawatiran sanksi legal yang akan mereka terima, penyitaan oleh pemerintah, bahkan pengenaan pajak. Pencegahan diperlukan untuk menangkal hal semacam tersebut di atas, yang bisa saja kemungkinan berasal dari sebuah ekskavasi di situs arkeologi dan menghasilkan perdagangan haram barang-barang purbakala. Dalam banyak elemen, disana ada dua sisi dari 
perdebatan mengenai bagaimana menjual barang purbakala dalam sebuah pasar, yang disokong oleh sistem perdagangan barang purbakala termasuk pedagang, kolektor, museum, dan beberapa arkeolog. Bahkan perdagangan internasional sekalipun sangat berhasrat dan mendukung gagasan yang kebanyakan mengganggap artefak adalah sesuatu yang pleonastis (benda bernilai lebih), memiliki nilai penting yang sangat signifikan dan bernilai penting dalam suatu budaya (diartikan sebagai bangsa yang kaya jika memiliki banyak tinggalan arkelogis).

Advokasi dan usaha menggugah (evocative) masyarakat diperlukan pada posisi seperti ini, agar tidak memancing orang dan pihak yang akan menjadikan barang purbakala menjadi sebuah komoditi perdagangan yang bisa saja dikirim secara bawah tanah, dijual dengan harga tinggi dan ketiadaaan kontrol. terdapat sebuah kemiripan dengan dunia narkoba dan perdagangan senjata. Dari perspektif ini, sebuah sanksi legal mengenai penjualan barang purbakala akan diletakkan perampok menjadi sebuah bisnis (Merryman, 1995; Shanks, 2001). Walaupun di Indonesia keadaan seperti ini belum terlihat terang-terangan dan masih terpendam (laten). Pada sisi lainnya dari perdebatan ini adalah hal yang berlawanan pada suatu perdagangan barang purbakala yaitu masalah legalitas dan ilegalitas. Terdiri atas arkeolog, pemerintah nasional, beberapa pekerja museum dan preservator budaya yang diklaim sebagai kelompok penyebab adanya penawaran barang purbakala dan perampok situs arkeologis dalam hal penyuplaian. Untuk mereka yang benar-benar jahat dalam sebuah perdagangan haram barang purbakala tersebut ialah kolektor. Hasilnya mereka menyokong sebuah sistem perdagangan barang purbakala yang seharusnya dilindungi dari destruksi. Wacana yang berkembang pada penjelasan tersebut merupakan sebuah skenario yang dipikirkan oleh pemerintah, sehingga dengan adanya keringanan atau pembebasan pajak, setidaknya akan mencegah orang untuk berpikir menjadikan barang purbakala sebagai komoditas, yang seharusnya diselamatkan dan dipreservasi, dikarenakan tinggalan arkeologis semacam itu sangat bernilai tinggi secara kultural yang bisa memperkuat kecintaan kita terhadap tinggalan masa lalu.

Undang-undang lain yang menyinggung terkait cagar budaya adalah Peraturan Menteri
Pekerjaan Umum dan Perumahan Rakyat RI Nomor 1/PRT/M/2015, pada pasal 28 disebutkan secara jelas mengenai kompensasi, insentif dan disinsentif.

Pasal 28

1. Pemerintah Kabupaten/Kota, Pemerintah Provinsi untuk DKI Jakarta, atau Menteri untuk bangunan gedung cagar budaya dengan fungsi khusus dapat memberikan kompensasi, insentif dan/atau disinsentif kepada pemilik, pengguna dan/atau pengelola bangunan gedung cagar budaya yang dilestarikan.

2. Pemberian kompensasi, insentif dan/atau disinsentif sebagaimana dimaksud pada ayat(1), dilakukan untuk mendorong upaya pelestarian oleh pemilik, pengguna dan/atau pengelola bangunan gedung cagar budaya yang dilestarikan.

Pasal 29

1. Kompensasi sebagaimana dimaksud dalam Pasal 28 ayat (1) adalah imbalan berupa uang dan/atau bukan uang dari pemerintah kabupaten/kota, Pemerintah Provinsi untuk DKI Jakarta, atau Menteri untuk bangunan gedung cagar budaya dengan fungsi khusus.

2. Kompensasi bukan uang sebagaimana dimaksud pada ayat (1) dapat berupa bantuan tenaga dan/atau bantuan bahan sebagai penggantian sebagian biaya pelestarian kepada pemilik, pengguna dan/atau pengelola bangunan gedung cagar budaya yang dilestarikan.

3. Pelaksanaan kompensasi yang bersumber dari pemerintah Kabupaten/Kota, Pemerintah Provinsi untuk DKI Jakarta, atau Menteri untuk bangunan gedung cagar budaya dengan fungsi khusus sesuai ketentuan peraturan perundang-undangan.

Peraturan Menteri Pekerjaan Umum dan Perumahan Rakyat RI Nomor 1/PRT/M/2015, pada pasal 28 disebutkan secara lugas yaitu mengenai perihal jika sebuah daerah memiliki bangunan gedung cagar budaya dengan fungsi khusus (misal bangunan bergaya Indies/ Eropa Kolonial) dapat diberikan kompensasi atau pun insentif kepada pemilik, pengguna dan/atau pengelola bangunan gedung cagar budaya yang dilestarikan tersebut. Negara memberikan sebuah jaminan bahwa tinggalan arkeologis berupa bangunan tersebut harus mendapatkan porsi dan 
perlakuan khusus dalam upaya pelestarian warisan budaya terutama tinggalan yang berbentuk bangunan.

Pada penjelasan tersebut merupakan sebuah cuplikan sederhana bagaimana sebuah situs, monumen atau bangunan, dapat dikaitkan relevansinya dengan produk hukum lainnya berkenaan dengan insentif dan kompensasi di luar Undang-undang Cagar Budaya Nomor 11 Tahun 2010. Situs atau monumen, agar dapat dikaitkan dengan masa sekarang perlu ditambahkan maknanya menjadi warisan, dalam hal ini tentunya adalah warisan budaya. Penambahan makna sebagai warisan budaya ini perlu disampaikan kepada masyarakat masa kini agar tergugah rasa kepemilikannya terhadap peninggalan masa lampau (Magetsari, 2016: 398).

Masih menurut Magetsari (2016), baik situs ataupun monumen perlu disajikan sebagai sebuah warisan yang artinya, tidak disajikan telanjang secara fisik, melainkan dilengkapi dengan maknanya. Demikian pemaknaan yang diberikan Pemerintah untuk cagar budaya dan situs bersejarah, dengan memberikan sebuah keringanan ataupun kompensasi agar masyarakat merasa lebih memiliki (sense of belonging). Masyarakat akan lebih sadar untuk melaporkan dan memiliki tanggung jawab untuk menjaga atau pun memelihara setiap tinggalan arkeologis yang telah bersinggungan dengan komunal di masyarakat yang ada dewasa ini.

Cagar budaya secara keabsahannya, tidak saja ada dalam peraturan perundang-undangan seperti telah diuraikan sebelumnya, tetapi lebih dari mengusung cita-cita mulia yang terkandung pada Undang-undang Dasar 1945 pasal 32 ayat 1 yang berbunyi: "Negara memajukan kebudayaan nasional Indonesia di tengah peradaban dunia dengan menjamin kebebasan masyarakat dalam memelihara dalam mengembangkan nilai-nilai budayanya."

Komunikasi yang dilakukan pemerintah melalui produk hukum yang ada, dalam mengatur tentang Cagar Budaya (cultural property) merupakan suatu hal yang sangat mendasar. Komunikasi ini diperlukan agar setiap individu atau perorangan, masyarakat atau komunitas yang terintegrasi satu dengan lainnya bisa menjaga tinggalan budaya sebagai aset yang harus dilestarikan. Esensi dari komunikasi seperti itu akan sangat memberikan pengaruh, dampak dan implikasi pada keseluruhan kehidupan manusia yang memiliki kemampuan untuk memaknai kembali arti penting tinggalan masa lalu sebagai sebuah khasanah kebudayaan yang bisa dibanggakan pada masa sekarang terlebih untuk generasi mendatang.

Proses komunikasi seperti ini diperlukan untuk memperkuat peran pemerintah dalam menerapkan kebijakan untuk menautkan pemahaman bahwa tinggalan budaya (materiality) selalu bisa diartikan bernilai penting dan bisa dikelola secara berkelanjutan (discursive simultaneously) tanpa mengenal ruang dan waktu. Kesadaran oleh masyarakat berkenaan dengan bagaimana mereka memandang cagar budaya (heritage)-nya harus terlebih dahulu dibangun dari pikiran mereka. Seperti yang juga pernah dikemukakan oleh Rodney Harrison dalam artikelnya berjudul The Politics of the Past: Conflict in the use of heritage in the modern world dalam buku "The Heritage Reader" (2008), menyatakan bahwa seseorang akan cenderung menjadi peduli dengan cagar budaya jika mereka mengalami keterikatan secara historis di dalamnya. Tahapan yang diutarakan meliputi:

1. Masyarakat secara metafora merasa mereka tidak kehilangan jejak atau 'runtuh memori kolektif" akan kesejarahan mereka sendiri.

2. Setelah mereka sadar mendapati diri mereka memiliki memori kolektif, tentu mereka akan terhindar dari fase neglect (pengabaian) akan tinggalan budaya. Mereka akan cenderung lebih peduli terhadap tinggalan kesejarahan mereka.

3. Tahap terakhir ialah masyarakat tidak akan melakukan predatory heritage ataupun pengrusakan akan nilai kesejarahan itu sendiri. (Harrison, 2008: 178-179).

Tahapan di atas merupakan sebuah gambaran mengenai manusia secara individu dan secara kelompok dalam masyarakat akan berperilaku terhadap cagar budaya yang ada di sekitarnya. Ketika mereka tidak menjadi predatory untuk heritage mereka sendiri baik dengan cara perampasan, pencurian, penggelapan, tidak melaporkan kepemilikan dan bahkan pengerusakan, maka itu dianggap suatu hal yang efektif demi kelangsungan kelestarian cagar budaya dimana beberapa regulasi perundang-undangan yang telah dibahas tersebut menjadi teraplikasikan. Cara pemerintah tersebut 
dapat dianggap suatu hal yang diperlukan demi komunikasi dialogis yang diharapkan terjadi (baca: komunikasi masyarakat dengan tinggalan budayanya).

\section{KESIMPULAN}

Negara telah memberikan perhatian khusus atas cagar budaya, baik produk hukum yang melibatkan masyarakat dan stakeholder yang ada. Peninggalan purbakala mendapatkan perhatian yang serius dari pemerintah dengan tidak menetapkan pajak laiknya seperti bangunan umum lainnya. Pemerintah secara tidak langsung juga melibatkan masyarakat untuk mau peduli dengan tinggalan arkeologis yang ada. Masalah pengembangan cagar budaya juga tidak luput dari perhatian pemerintah. Permasalahan di lapangan juga harus menjadi perhatian arkeolog. Arkeolog dituntut untuk mengerti dan memahami secara garis besar teori dan praktik hukum, khususnya hukum tertulis, yang di dalamnya banyak upaya yang bisa dilakukan guna perlindungan terhadap cagar budaya.

Pemberian kompensasi, insentif serta pengurangan pajak dilakukan untuk mendorong upaya pelestarian oleh pemilik, pengguna atau pengelola bangunan gedung cagar budaya yang dilestarikan. Kendati kompensasi yang diterima pemilik dan pengelola sebagaimana dimaksud dalam Pasal 28 ayat (1) Peraturan Menteri Pekerjaan Umum dan Perumahan Rakyat RI Nomor 1/PRT/M/2015 dan Undang-undang Nomor 12 Tahun 1994 mengenai PBB (Pajak Bumi Bangunan) adalah bukan berupa imbalan uang, namun pemerintah berusaha memberikan keringanan pajak, dapat berupa bantuan tenaga dan/atau bantuan bahan sebagai penggantian sebagian biaya pelestarian kepada pemilik, pengguna dan/atau pengelola cagar budaya. Semua itu berdasarkan sebagai perhatian pemerintah dalam rangka pelestarian cagar budaya (heritage) baik tingkat Provinsi, Kabupaten, dan Kotamadya.

Kebijakan pengelolaan pemerintah seperti ini merupakan usaha yang setidaknya bisa menyasar masyarakat yang memiliki warisan budaya/cagar budaya. Masyarakat itu sendiri merupakan faktor yang sangat penting sebagai rekanan pemerintah dalam melestarikan setiap temuan arkeologis yang ada. Persepsi masyarakat akan tinggalan budaya yang dimilikinya harus terbangun sedemikian rupa agar masyarakat memiliki koneksitas antara pengetahuan, imajinasi tentang masa lampau, serta identitas asal usulnya dapat menjadi dasar pemikiran dalam melihat cagar budaya yang tidak melulu dilihat dengan uang atau komoditas tertentu. Kebijakan pemerintah yang termaktub dalam Undang-undang CB Nomor 11 Tahun 2010, setidaknya bisa menggambarkan persoalan tersebut.

Sebagai penutup dari apa yang pernah dikemukakan oleh Mc. Gimsey yang berkaitan dengan adanya dialogis antara orang (people) and barang (things) dalam bukunya Public Archaeology:

"pada dasarnya arkeologi mengungkapkan masyarakat masa lalu melalui benda budaya (material culture). Benda budaya adalah warisan budaya untuk semua orang. Karenanya semua orang harus bisa memiliki akses dan mendapatkan informasi arkeologi, jadi semua orang memiliki hak dan kewajiban kolektif terhadap arkeologi." (Mc. Gimsey, 1972: 5-6).

\section{Ucapan Terima Kasih}

Penulis berterima kasih kepada seluruh pihak yang turut membantu penyusunan penelitian kecil ini hingga sampai berwujud sebuah artikel ilmiah. Penulis juga mengucapkan terima kasih kepada Kapata Arkeologi yang telah mempublikasikan artikel ini. Semoga artikel ini menjadi informasi dan pengetahuan yang bermanfaat.

$* * * * *$

\section{DAFTAR PUSTAKA}

Harrison, R. (2008). The Politics of the Past: Conflict in the use of heritage in the modern world. In Graham, F., Jameson, J., \& Scofield, J. (Ed.), The Heritage Reader. New York: Routledge.

Harrison, R. (2013). Heritage Critical Approaches. London: Routledge.

Kansil, C. S. T. (2014). Pengantar Ilmu Hukum Indonesia. Jakarta: Rineka Cipta.

Kersel, M. (2009). Walking a Fine Line, Obtaining sensitive Information Using a Valid Methodology. In Sorensen, M. L. S., \& Carman, J. (Ed.), Heritage Studies Methods and Approaches (pp. 178-200). New York: Routledge.

Magetsari, N. (1990). Masalah Pembidangan Dalam Arkeologi Indonesia. In Sedyawati, E. (Ed.), 
Monumen Karya Persembahan Untuk Prof. Soekmono (pp. 1-6). Depok: Seri Penerbitan Ilmiah Universitas Indonesia.

Magetsari, N. (2016). Perspektif Arkeologi Masa Kini Dalam Konteks Indonesia. Jakarta: Penerbit Buku Kompas.

Mc. Gimsey, C. (1972). Public Archaeology. New York: Seminar Press.

Peraturan Menteri Pekerjaan Umum dan Perumahan Rakyat RI. Tentang Bangunan Gedung Cagar Budaya Yang Dilestarikan, Pub. L. No.1/PRT/M/2015 (2015).

Shanks, H. (2001). How to Stop Looting. In Silberman \& Frerichs (Ed.), Archaeology and Society in the 21 $1^{\text {st }}$ Century: The Dead Sea Scrolls and Other Case Studies. Jerusalem: Israel Exploration Society.

Suleiman, S. R., Mulia, N. S., Anggraeni, \& Supandi, F. X. (1976). 50 Tahun Lembaga Purbakala dan Peninggalan Nasional. Jakarta: Pusat Penelitian Arkeologi Nasional.

Tanudirjo, D. A. (1995). Theoretical Trends in Indonesian Archaeology. In Ucko, P. (Ed.), Theory in Archaeology, a World Perspective (pp. 61-75). London: Routledge.

Tanudirjo, D. A. (2003). Warisan Budaya untuk Semua, Arah Kebijakan Pengelolaan Warisan Budaya Indonesia di Masa Mendatang. In Makalah Kongres Kebudayaan V. Bukit Tinggi: Sumatera Barat.

Tanudirjo, D. A. (2010). Undang-undang Cagar Budaya dalam Perspektif Arkeologi. In Makalah Diskusi Pembahasan Undang-undang tentang Cagar Budaya di Balai Pelestarian Peninggalan Purbakala Daerah Istimewa Yogyakarta. Yogyakarta: Balai Pelestarian Peninggalan Purbakala D.I. Yogyakarta.

Tim Penyusun. (2008). Kamus Besar Bahasa Indonesia Pusat Bahasa. Jakarta: Departemen Pendidikan Nasional.

Undang-undang Dasar Negara Republik Indonesia Tahun 1945.

Undang-undang RI. Tentang Cagar Budaya, Pub. L. No. 11 (2010).

Undang-undang RI. Tentang Pajak Bumi dan Bangunan, Pub. L. No. 12 (1994).

Undang-undang RI. Tentang Pemerintah Daerah, Pub. L. No. 23 (2004). 